\title{
Kloning Manusia dan Masalah Sosial-Etik
}

\author{
Oleh: Aman ${ }^{1}$
}

\begin{abstract}
s
In the context of Sociological, human cloning has been taken into consideration of endangering and threatening the social order which has been developed by man since their existence on earth. Cloning is also bringing negative upshot not only to social order but also to the social interaction which has been accepted as the basis of the harmony and peace between individual. The biological technology utilization was once only laid a hand on scientific knowledge ever since it was resulted on or after scientific exploration process. Yet directly or indirectly, cloning might originate the devastation of the basic principle of religion with its universal ethics. Cloning not only lies in the scientific land but further, it has made a long jump over the discipline of science such as ethic, Sociology, Economy, gender and religion.
\end{abstract}

Keywords: human cloning, social problems, ethic, religion

\section{A. Pendahuluan}

Pertanyaan yang paling awal dari sebuah review pembuka mengenai kloning pada manusia adalah: akankah kloning pada manusia menjadi suatu hal yang normatif di planet bumi ini? Pertanyaan ini tampaknya sangat sederhana sekali namun tidak cukup hanya dijawab ya atau tidak, melainkan memerlukan pemikiran yang cermat agar kita tidak terjebak pada pemikiranpemikiran gelap yang mengabaikan prinsip-prinsip normatif dan humanis. Harus diperhitungkan dimensi kebaikan dan keburukan dari prosesi kloning tersebut sehingga tidak keliru dalam mengambil kesimpulan yang sangat berpengaruh terhadap kemaslahatan umat. Kehidupan kolektif manusia harus memerhatikan berbagai dimensi tidak sekedar terkait masalah iptek saja, tetapi juga unsur

${ }^{1}$ Dosen Jurusan Pendidikan Sejarah Fakultas Ilmu Sosial dan Ekonomi Universitas Negeri Yogyakarta. 
normativitas memerlukan jawaban atas semua pertanyaan yang sangat substantif dan sensitif.

Bila ditinjau dari sudut etika, penerapan kloning dapat dilihat dari dua sudut berbeda, yaitu deontologi dan teleologi. Pada paham deontologi, penilaian etis tidaknya suatu perbuatan lebih ditekankan pada perbuatan itu sendiri. Tokoh utama paham ini adalah Immanuel Kant yang terkenal dengan teori categorical imperative. Menurutnya, perbuatan yang secara umum (universal) dinyatakan terlarang, maka apapun alasannya tidak boleh dilakukan. Sebaliknya, paham teleologi lebih menilai pada tujuan atau akibat yang dituju pada perbuaatan itu. Kalau tujuannya berupa suatu kebaikan, maka perbuataan itu masih diperbolehkan untuk dilakukan, sering juga penganut paham itu disebut sebagai konsekuensialis. Yang jelas, kedua paham besar etika ini menghendaki bahwa apapun yang dilakukan adalah demi kebaikan dan untuk kesejahteraan manusia.

Dari sudut pandang sosiologis, kloning manusia dikhawatirkan akan mengancam pranata sosial yang telah dibangun oleh umat manusia sejak keberadaannya dimuka bumi. Kloning secara tidak langsung juga berimbas negatif terhadap pranata sosial dan interaksi sosial yang selama ini diyakini sebagai basis kerukunan dan kedamaian antar sesama manusia. Sementara dari sudut pandang ekonomi, kloning dapat juga memudarkan etika bisnis yang berwajah humanis. Saat ini, kegiatan bisnis penelitian yang yang terkait dengan kloning semakin gencar dilakukan seperti pembuatan domba Dolly. Bila proyek ini berhasil tidak dapat dihindarkan terjadinya transaksi bisnis manusia kloning. Perdagangan kloning manusia seperti ini, tentu saja telah meletakkan martabat manusia setara dengan hewan dan tumbuhan. Dari sudut gender, kloning juga mendatangkan efek negatif bagi posisi perempuan. Dari sudut pandang gender, penerapan kloning manusia tetap saja mendeskriditkan harkat dan martabat manusia.Terakhir dari sudut agama, penerapan kloning tidak disinggung secara eksplisit dan spesifik.

Dalam konteks perkembangan ilmu pengetahuan dan teknologi, kloning adalah prestasi besar pada akhir abad yang lalu sehingga sampai saat ini menjadi topik pembicaraan baik dalam 
tulisan maupun pertemuan baik dalam maupun luar negeri. Untuk membahas kloning, maka berbagai terminologi digunakan seperti sudut moral, hukum, agama, psikologi, medis, biologi, bahkan sampai sudut pandang ekonomi. Hal ini mengindikasikan bahwa betapa kloning memiliki dampak yang sangat besar bagi masa depan peradaban manusia. Keberhasilan yang spektakuler pada binatang, tidak menutup kemungkinan diikuti dengan tahap berikutnya yakni kloning pada manusia. Jika hal itu terjadi dalam bentuk yang massif, maka dapat dibayangkan terjadinya perubahan sosial yang besar karena lahirnya makhluk "baru" yang bisa jadi memiliki karakteristik lebih baik atau bahkan lebih buruk. Terkait dengan itu, tulisan ini mencoba menguak masalah kloning serta dampaknya bagi sosialitas kehidupan manusia yang serba kompleks dan serba ingin tahu terhadap hal ihwal keilmuan terutama yang mereka geluti.

\section{B. Serba-serbi Kloning}

Secara teknis, kloning berarti meniru. Teknik ini bermaksud membentuk organ hidup buatan yang mirip dengan organ aslinya. Caranya dengan mengambil inti sel dari sel tubuh ke sel telur. Begitulah yang terjadi dalam kloning makhluk hidup lengkap pertama di dunia, yang dilakukan oleh peneliti pada Roslin Institute, Edinburgh, Skotlandia, pada 1996. Mereka berhasil mengkloning domba yang kemudian diberi nama Dolly. Keberhasilan tim pimpinan Dokter Ian Wilmut ini mendorong para peneliti melakukan berbagai riset kloning terhadap tikus, kera, sapi, babi, dan kuda. Berhasil, konon. Sampai akhirnya timbul pikiran: mengapa tak mencoba mengkloning makhluk paling" sempurna", yakni manusia?

Dalam bahasa Inggris, istilah kloning yang berasal dari kata cloning, diartikan sebagai suatu usaha untuk menciptakan duplikat suatu organisme melalui proses yang aseksual (Soetandyo Wignjosoebroto, 1997). Atau dalam perkataan lain kloning berarti penggandaan atau membuat foto kopi dari suatu makhluk dengan cara-cara nonseksual. Istilah tersebut pada awalnya dipakai dalam dunia tanaman, yang berarti sekumpulan tanaman yang didapatkan dari pembiakan vegetatif atau pembiakan tanpa perkawinan seperti pembiakan yang menggunakan stek atau cangkok. Pembiakan 
vegetatif pada tanaman tersebut bertujuan untuk memperoleh pasokan bibit tanaman unggul dibidang agrikultura, hotrikultura, maupun klorikultura. Oleh karena itu kloning pada tanaman sebenarnya bukan hal yang baru, tetapi yang baru adalah keberhasilan kloning pada hewan.

Hasil pembiakan vegetatif tanaman mengandung perangkat gen yang sama dengan induknya, dan akan menunjukkan sifat-sifat fisik yang sama pula, misalnya tebu yang manis, mangga yang besar dan enak rasanya, buah anggrek yang indah, dan lain sebagainya. Dalam konsepsi ini, anak kembar yang berasal dari satu telur akan memiliki perangkat gen yang sama, dengan demikian antara keduanya sering sulit dibedakan satu sama lain. Dipandang dari kesamaan perangkat gennya, maka dua saudara kembar satu telur dapat dianggap sebagai suatu klon yang terjadi secara alami. Ini tampaknya merupakan suatu isyarat mengenai eksistensi "Teknologi Ketuhanan".

Secara etimologis, ada dua pengertian kloning, yaitu (1) klon sel yang menduplikasi sejumlah sel dari sebuah sel yang mempunyai sifat-sifat genetik identik, dan (2) klon gen atau molekuler, artinya sekelompok salinan yang bersifat identik yang direolikasi dari satu gen dimasukkan dalam sel inang. Sedangkan secara terminologis, kloning adalah proses pembuata sejumlah besar sel atau molekuler yang seluruhnya identik dengan sel atau molekul asalnya. Kloning dalam bidang genetika merupakan replikasi segmen DNA tanpa melalui proses seksual.

Dengan demikian secara sederhana dapat disebutkan bahwa bayi "klon" dibuat dengan mempersiapkan sel telur yang sudah diambil intinya kemudiaan digabungkan dengan sel donor yang merupakan sel dewasa dari suatu organ tubuh. Hasil gabungan tersebut kemudian ditanamkan kedalam rahim dan dibiarkan berkembang dalam rahim sampai lahir. Secara teoritis, prosedur dan mekanisme kloning terhadap makhluk hidup sedikitnya harus melalui empat tahap yang diurutkan secara sistematis. Keempat tahap itu adalah: 1) Isolasi fragmen DNA, 2) penyisipan fragmen DNA ke dalam vektor, 3) transformasi, 4) seleksi hasil kloning. Dalam tataran aplikasi, rentetan proses kloning dapat dilakukan 
Kloning Manusia dan Masalah Sosial-Etik

dengan mengikuti beberapa langkah konkrit berikut: Mempersiapkan sel sterm, yaitu suatu sel awal yg akan tumbuh menjadi berbagai sel tubuh. Diambil dari makhluk hidup yang hendak dikloning. Sel sterm diambil inti selnya yang mengandung informasi genetik kemudin dipisahkan dari sel. Mempersiapkan sel telur. Inti sel dari sel sterm diimplementasikan ke sel telur. Sel telur dipicu supaya terjadi pembelahan dan pertumbuhan. Sel embrio yang terus memmbelah mulai memisahkan diri dan siap diimplemetasikan ke dalam rahim. Embrio tumbuh dalam rahim menjadi janin dengan kode genetik persis sama dengan sel sterm donor. Kloning dapat dibedakan menjadi tiga macam, yaitu kloning embrional adalah teknik yang dilakukan untuk memperoleh kembar identik, meniru apa yang terjadi secara alamiah. Kloning DNA dewasa atau reproduktif adalah rekayasa genetik untuk memperoleh duplikat dari seorang individu yang sudah eksis. Kloning terapeutik adalah rekayasa genetik untuk memperoleh sel, jaringan atau organ dari satu individu tertentu untuk tujuan pengobatan atau perbaikan kesehatan. Selain itu kloning juga menjanjikan keuntungan, antara lain: Proses pembuahan dengan metode ini dapat menolong pasangan tidak subur untuk memperoleh keturunan. Manusia dapat mengkloning ginjal untuk kebutuhan pencangkokan ginjal bagi yang mengalami gagal ginjal. Dapat mengkloning tulang sumsum untuk anak dan dewasa untuk mengobati leukimia. Melalui kloning, manusia dapat mempelajari bagaimana menghidupkan dan mematikan (Dito Anurogo, 2005).

Usaha kloning sebenarnya bukan usaha baru. Sejak bertahuntahun para sarjana terus meneliti kemungkinan membuat satu individu baru tanpa harus mempertemukan unsur jantan (spermatozoa) dengan unsur betina (ovum). Masing-masing sarjana di beberapa institut riset mengembangkan metodanya masingmasing. Masing-masing dengan "sepotong" keberhasilan yang kemudian mengilhami penelitian lainnya lagi. Dalam penelitiannya, sarjana Ian Wilmut dari Roslin Institute di Edinburgh-Inggris, menggunakan tiga ekor domba betina. Domba pertama digunakan DNA-nya, yang diambil dari satu sel ambing-nya (kelenjar susu); domba kedua digunakan sel telur-nya (ovum), setelah membuang 
DNA-nya terlebih dahulu. Sel berisi DNA (dari domba pertama) lalu didekatkan dengan ovum tanpa DNA (dari domba kedua) seperti dua busa sabun yang ditempelkan satu sama lain. Dengan kejutan listrik (yang mirip dengan kejutan listrik yang terjadi pada pembuahan alami) sel ovum ini ternyata menerima DNA dari domba pertama. Ternyata lagi, ovum yang sudah "dibuahi" ini berkemampuan membelah diri berkembang menjadi emrio. Lalu terakhir, embrio ini dimasukkan ke kandungan domba yang ke tiga. Setelah sekian bulan, lahirlah "Dolly"-mammalia pertama yang dilahirkan tanpa ayah (dalam arti sesungguhnya). Untuk diketahui DNA adalah bagian dari inti sel yang berisi "informasi" atau "blue print" tentang bagaimana model-fisik dan mental-dari individu yang akan dihasilkan.

Meskipun keberhasilan tersebut bukanlah kloning murni karena melibatkan tiga individu (domba), namun yang istimewa dari keberhasilan Ian Wilmut dan kawan-kawannya adalah bahwa ketigatiganya dalah domba betina, dan sel yang diambil adalah sel dewasa. Untuk diketahui penelitian sebelumnya, diantaranya Jerry Hall dari Amerika Serikat di tahun 1993, menggunakan sel embrio-sel yang memang diketahui bisa membelahdiri dan berkembang menjadi satu individu utuh. Sedangkan Ian Wilmut menggunakan sel dewasa (dari domba dewasa) tapi ternyata bisa menjadi domba utuh. Sebelumnya, dikatakan bahwa satu sel dewasa hanya bisa berkembang menjadi sel serupa. Sel otak menjadi sel otak, sel tulang menjadi sel tulang dan seterusnya. Dalam kasus "Dolly", sel ambing (kelenjar susu) ternyata mempunyai kemampuan menjadi domba utuh-Si Dolly. Penelitian Ian Wilmut, tampaknya akan menjadi pelopor dalam penelitian yang akan menghasilkan kloning murni, yakni individu yang dihasilkan dari satu individu dewasa (Tjahjadi, 1997).

\section{Kloning Pada Hewan Sebuah Prestasi Ilmuwan}

Pembiakan pada hewan berbeda dengan pembiakan pada tanaman yang melalui penyetekan maupun penyangkokan. Pada hewan, pembiakan dilakukan melalui "galur murni" untuk mendapatkan sifat-sifat unggul yang sama dengan induknya. Hewan 
galur murni belum dapat dianggap klon, karena mereka hanya memiliki sejumlah gen yang sama yakni gen-gen yang menentukan sifat-sifat unggul tersebut. Sedangkan gen-gen lainnya belum tentu sama.

Terobosan penting dalam penggandaan hewan adalah ditemukannya teknik IVF (In Vitro Fertilization) yang antara lain dilakukan pada sapi. Pada teknik ini dilakukan fertilasi in vitro atau pembuahan di luar tubuh dengan mencampur sperma dan ovum hewan bibit unggul. Setelah terjadi pembuahan, zigote dibiarkan membelah sehingga menghasilkan embrio (mudghoh). Embrio kemudian ditanam dalam rahim induk pengganti (surrogate mother) yang terlebih dulu disuntik hormon agar uterus atau rahim induk pengganti tersebut dalam keadaan siap menerima embrio. Melalui teknik ini maka dihasilkan hewan bibit unggul lainnya yang lebih banyak dibandingkan melalui perkawinan biasa yang terbatas. Pada manusia, teknik ini dikenal dengan istilah "bayi tabung".

Kloning pada hewan ternyata lebih sulit mengalami dediferensiasi. Keberhasilan kloning pada hewan, dibuktikan di antaranya oleh John Gurdon pada tahun 1962 seorang ilmuwan Amerika. Gurdon berhasil mengkloning katak melalui teknik transplantasi inti (nuclear transplantation), yakni dengan memasukkan inti sel epitel usus katak pada sel telur katak jenis lain yang tidak dihilangkan intinya. Percobaan dilakukan berulang kali mulai dari tingkat efisiensi $2 \%$ saja sampai tingkat efisiensi $40 \%$.

Keberhasilan kloning pada katak, maka para ilmuwan meramalkan keberhasilan kloning pada mamalia dan bahkan pada manusia. Ramalan tersebut betul-betul menjadi kenyataan karena dalam kurun waktu beberapa tahun kemudian, lahirlah si Dolly, hewan mamalia pertama yang berhasil dikloning oleh Ian Wilmut dan Ceith Campbell, ilmuwan Skotlandia. Sebagainama halnya Gurdon, tingkat efisiensi yang dicapai Wilmut juga rendah. Dolly lahir setelah dilakukan 227 kali percobaan. Ini berarti 1: 227 yakni sekitar $0.4 \%$.

Keberhasilan Wilmut sebenarnya telah didahului oleh Trounson, rekan dekat Wilmut yang mengembangkan teknik IVF. Dengan teknik serupa, Trounson telah menghasilkan anak domba 
dengan memfusikan sel embrio domba dan sel telur yang dihilangkan intinya. Tetapi keberhasilan Trounson ini tidak dipublikasikan secara luas sehingga tidak seheboh kelahiran Dolly. Setelah kelahiran Dolly ini Don Wolf dari Oregon, Amerika Serikat juga mengumumkan kloning dari embrio kera. Kera hasil pengklonan genetika tersebut kemudian diberi nama Tetra. Kemudian keberhasilan Yoko Kato dan teman-temannya dari Jepang yang berhasil mengklon delapan anak sapi sekaligus merupakan prestasi yang gemilang para ilmuwan Asia. Keberhasilan tersebut merupakan terobosan teknologi kloning yang belum dikembangkan sebelumnya.

Kelahiran Tetra dengan teknik pembelahan embrio yang masih muda memang sangat berbeda dengan domba Dolly hasil pengklonan yang sempat menggegerkan dunia ilmu pengetahuan, etika, dan agama. Hal ini dikarenakan Dolly diperoleh melalui metode pengklonan transfer nuklir dengan mengambil satu nukleus (inti) dari sebuah sel dewasa domba untuk memprogram ulang sebuah sel telur yang belum dibuahi. Menurut Gerald Schatten, dikatakan bahwa produk-produk bioteknologi transfer nuklir seperti Dolly belum bisa dikatakan 100\% hasil pengklonan. Sementara teknik yang digunakan untuk menciptakan Tetra mampu menghasilkan kera identik secara genetik.

Menurut Schatten, lahirnya Tetra adalah lonjakan besar dalam bioteknologi pengklonan. Hal ini dikarenakan kera memiliki relasi biologis yang lebih dekat dengan manusia. Berdasarkan catatan medis, teknik klon yang digunakan oleh schatten pernah dilakukan terhadap embrio manusia oleh Jerry Hall pada tahun 1933. Sebagaimana Schatten, Hall mengaku pernah mengklon embrio manusia dengan teknik pemisahan. Tetapi Hall memutuskan untuk menghancurkan sendiri dan tidak melanjutkan penelitiannya itu.

Akankah keberhasilan kloning pada binatang menjamin keberhasilan kloning manusia? Tak semua ilmuwan sepaham menjawab pertanyaan ini. Bahkan Ian Wilmut, Direktur Roslin Institute, Skotlandia, yang "ayah" domba Dolly, menganggap kloning masih tak aman bila diterapkan pada manusia. Ia menilai, bayi kloning akan meninggal setelah lahir. Kalaupun bisa bertahan hidup, 
bayi tadi akan mengalami problem genetika. Sebab, ada gen yang mungkin tumbuh tidak normal. "Jika dibiarkan, pertumbuhan gen tadi bisa menjurus kanker," katanya. Wilmut mengaku, sebelum "menciptakan" Dolly, pada 1997, ia melakukan 227 percobaan. Ia mengeluh: Dolly, hasil ciptaannya, juga tumbuh tak genah. Tubuh domba buatan itu kelihatan gemuk, dan wajahnya tampak lebih tua dari usianya. Sampai kini Wilmut dan koleganya masih mencari tahu penyebabnya. Rudolph Jaenich, ahli biologi pada Institut Whitehead, Massachusetts Institute of Technology, Amerika Serikat, juga menganggap teknologi kloning lebih banyak merugikan. Angka kematian binatang hasil kloning termasuk tinggi. Dari serangkaian percobaan, $18 \%$ tikus dan $38 \%$ domba hasil kloning mati. "Tingkat keberhasilannya masih sangat kecil," katanya (Syahrir Wahab, 2001).

\section{Kloning Pada Manusia dan Masalah Sosial-Etik}

\section{Masalah Sosial-Etik}

Keberhasilan kloning pada hewan terutama pada kera sebagai hasil pengembangan ilmu pengetahuan dan teknologi, sangat menghebohkan para ilmuwan maupun orang awam. Hewan kera adalah jenis primata yang paling dekat dengan struktur organ manusia. Jika pada kera kloning dapat berhasil, maka pada manusia kemungkinan berhasilnya kloning sangat besar. Namun pertanyaannya apakah para ilmuwan telah siap dengan segala resiko yang menyertainya apabila usaha kloning pada manusia tetap dilanjutkan.

Karakteristik genetis yang membedakan primata dengan mamalia lain, secara teknis akan mempermudah upaya mengkloning manusia daripada kloning terhadap domba, sapi, babi, dan tikus. Ini disebabkan, karakteristik genetis tersebut mampu mencegah munculnya halangan utama seperti yang ditemui dalam upaya mengkloning binatang, kata para peneliti di Universitas Duke, Washington.

Primata seperti manusia, gorila, dan monyet, memiliki dua gen yang berfungsi melakukan peniruan yang membantu mengatur pertumbuhan janin. Artinya, bayi yang dikloning akan dilindungi dari perkembangan terlalu cepat. Gejala inilah yang 
terjadi pada upaya kloning hewan, kata para ilmuwan tersebut. Dalam gejala yang disebut dengan "sindrom janin besar", banyak bayi mamalia hasil kloning yang tumbuh terlalu cepat secara tidak wajar di dalam rahim induk, dan biasanya mati beberapa saat sebelum atau sesudah lahir. Bayi kloning pada mamalia juga sering memiliki paru-paru yang tidak berkembang dengan baik dan kurang daya tahan terhadap penyakit.

Pengumuman perusahaan bioteknologi Advanced Cell Technology (ACT) Inc dari Worcester, Massachusetts, tentang keberhasilannya melakukan kloning terapeutik, menyulut kembali pro-kontra kloning pada manusia. Meski yang dilakukan bukan kloning reproduksi, yaitu membuat manusia tiruan dari orangtua, melainkan kloning terapeutik yang menghentikan proses pada tahap embrio untuk diambil sel stem alias sel tunas untuk mengganti jaringan organ tubuh yang sakit, tindakan itu tetap mendapat tantangan, bahkan oleh Presiden Amerika Serikat George W Bush.

Namun, tidak semua menentang. Anggota House of Representative AS terbelah. Sebagian berpendapat, kloning terapeutik merupakan hal buruk. Menggunakan embrio hasil kloning untuk membantu orang sakit sama juga membunuh manusia untuk mendapat organ tubuhnya. Sebaliknya yang pro berpendapat, tidak selayaknya membiarkan jutaan orang menderita sakit dan meninggal karena menganggap sekelompok sel lebih penting. Menurut mereka, memanfaatkan embrio dalam tahap awal perkembangan tidak sama dengan membunuh manusia.

SEL stem menurut situs National Institutes of Health AS merupakan sel yang memiliki kemampuan untuk membelah dalam jangka waktu tak terba-tas dan mampu membentuk sel apa pun. Saat sel telur bertemu dengan sperma akan terbentuk sel tunggal yang mempunyai kemampuan membentuk seluruh organ. Sel yang telah dibuahi itu disebut totipotent atau mempunyai potensi total. Jika diletakkan dalam rahim mampu berkembang menjadi janin. 
Setelah mengalami pembelahan sel beberapa kali, sel totipotent menjadi blastosit berupa sekelompok sel dalam rongga yang dikelilingi sel selubung. Sel selubung akan berkembang menjadi plasenta dan jaringan yang mendukung perkembangan janin, sedangkan sel bagian dalam berkembang menjadi pelbagai organ tubuh. Sel ini disebut pluripotent.

Sel stem atau sel tunas ini yang menjadi obyek penelitian ACT. Bedanya, ACT membuat sel tunas dengan mengganti inti sel telur donor dengan inti sel kulit. Sel telur yang sudah diganti intinya kemudian dirangsang untuk membelah sampai tahap blastosit dan diekstraksi sel tunasnya untuk mengembangkan jaringan organ tubuh. Teknik ini, menurut Wakil Presiden ACT Dr Robert Lanza, dapat digunakan untuk pengobatan pelbagai penyakit yang mengancam kehidupan, seperti diabetes, stroke, kanker, AIDS serta penyakit neurodegeneratif seperti Parkinson dan Alzheimer, dengan mengarahkan perkembangan sel tunas menjadi sel tertentu untuk menggantikan jaringan tubuh yang terserang penyakit.

Menurut Prof dr Sangkot Marzuki PhD DSc, Diretktur Lembaga Biologi Molekular Eijkman, menyatakan, sel tunas juga bisa diperoleh dari sumsum tulang maupun sel darah tepi yang bisa membentuk pelbagai jenis darah, baik darah merah, darah putih maupun keping darah. Biasanya digunakan untuk terapi kanker darah (leukemia). Sel tunas ini disebut multipotent. Namun, dalam teknologi rekayasa jaringan, orang mau sel pluripotent, yaitu yang berasal dari embrio (embryonic stem cell). Walau mampu membentuk pelbagai jenis sel, sel multipotent hanya mampu membentuk sel tertentu. Sel tunas darah membentuk pelbagai sel darah, sel tunas kulit membentuk pelbagai jenis sel kulit dan sebagainya. Teknik kloning atau transfer inti sel digunakan untuk mencegah respons imun dari tubuh penerima. Karena itu, dibuat embrio menggunakan inti sel dari orang yang akan mendapat transplantasi sel tunas, sehingga pasti sesuai dan tidak mengalami penolakan oleh tubuh (Atika Walujani, 2001). 
Pada umumnya, mayoritas ilmuwan menolak kloning manusia, namun demikian siapa yang dapat menjamin bahwa satu dari dua ilmuwan tidak akan melakukannya secara diamdiam apabila seorang yang kaya raya pembuatan klon terhadap dirinya. Berbeda dengan kloning terhadap manusia, kloning pada hewan tidak mendapat pertentangan dari para ilmuwan. Teknik kloning hewan apabila telah berhasil disempurnakan sehingga efisiensinya meningkat, akan berhasil menyediakan hewanhewan bibit unggul untuk menggantikan teknik-teknik yang sekarang sudah ada (Imam Musbikin, 2001: 57).

Memang pada dasarnya, kloning terhadap manusia merupakan sebuah keberhasilan para ilmuwan Barat dalam memanfaatkan sains yang akhirnya mampu membuat sebuah kemajuan pesat yang telah melampaui seluruh ramalan manusia. Betapa tidak, cara ini dianggap sebagai jalan untuk memperbaiki kualitas keturunan: lebih cerdas, kuat, rupawan, ataupun untuk memperbanyak keturunan tanpa membutuhkan proses perkembangbiakan konvensional. Revolusi ini semakin memantapkan dominasi sains Barat terhadap kehidupan manusia, termasuk kaum Muslim (Denny Kodrat, 2003).

Apalagi, efek berikutnya dari perkembangan revolusi ini yaitu penggunaan dan pemanfaatannya akan selalu didasarkan pada ideologi tertentu. Bagi kaum Muslim sendiri, meskipun eksperimen ilmiah dan sains itu bersifat universal, dalam aspek penggunaannya harus terlebih dulu disesuaikan dengan pandangan hidup kaum Muslim. Kloning setidaknya memberikan dua persoalan besar pada kita terkait dengan historisitas dan normativitas. Persoalan yang pertama adalah terkait dengan kontroversi adanya "intervensi penciptaan" yang dilakukan manusia terhadap "tugas penciptaan" yang semestinya dilakukan oleh Allah SWT. Dan persoalan yang kedua adalah bagaimana posisi syariat menghadapi kontroversi pengkloningan ini. Apakah syariat mengharamkan atau justru sebaliknya menghalalkan.

Barangkali kita semua menyepakati bahwa alam semesta telah didesain sedemikian rupa sehingga terdapat hukum yang 
sangat rapi untuk mengendalikan dan menjalankan alam semesta ini. Adanya peraturan dan hukum alam ini tentu saja mengharuskan adanya Sang Pengatur dan Pencipta. Allah SWT berfirman, "Sesungguhnya Kami ciptakan segala sesuatu menurut ukuran" (Q.S. Al-Qamar: 49) dan dalam ayat lain, "...dan Dia telah menciptakan segala sesuatu, dan Dia menetapkan ukuranukurannya dengan serapi-rapinya" (Q.S. Al-Furqaan: 2).

Dua ayat di atas memiliki pemahaman bahwa Allah SWT telah menciptakan segala sesuatu dengan memperhitungkan ukuran dan kesesuaian, serta telah mempersiapkannya dengan kondisi-kondisi yang cocok. Oleh karena itu, penciptaan alam semesta sesungguhnya telah terlaksana dengan pertimbangan yang sangat bijaksana, bukan tanpa pertimbangan. Penciptaan alam semesta ini merupakan "penciptaan sesuatu dari ketiadaan (creatio ex nihillo) menjadi ada" bukan mengadakan sesuatu dari apa yang sudah ada.

Dengan logika ini, kloning terhadap manusia bukanlah suatu penciptaan, melainkan merupakan "pembuktian" dari keagungan dan kekuasaan Allah SWT. Atau dengan kalimat lain, kloning hanyalah penemuan (invention) kecil dari sejumlah hukum alam dan rahasia alam yang tidak ada unsur penciptaan di dalamnya. Alasannya, penemuan ini bukan "mengadakan" sesuatu dari yang tidak ada, melainkan hanya menyingkap apa yang sudah ada.

Oleh karena itu, semakin pesat dan majunya sains dengan banyak ditemukan rahasia dan hukum alam oleh para ilmuwan, sejatinya semakin bertambahlah tanda-tanda kebesaran Sang Pencipta (al-Khaliq), kesempurnaan kekuasaan-Nya, dan kerapian hikmah-Nya, serta semakin takjub dan tunduklah manusia. Bukan malah bersikap arogan ingin menyamai atau bahkan melampaui kekuasaan Allah SWT.

Kesan munculnya "intervensi penciptaan" yang dilakukan manusia sebenarnya dapat terbantahkan dengan sendirinya. Sebab bagaimanapun, dalam fakta kloning manusia, ilmuwan (masih dan akan terus) membutuhkan sesuatu yang telah ada (rahim manusia) untuk pengkloningan itu. Tanpa adanya 
pemanfaatan rahim, pengkloningan tidak akan berjalan. Juga dipahami bahwa dengan penemuan kloning ini kita dapat mengatakan bahwa sel tubuh manusia memiliki potensi menghasilkan keturunan jika inti sel tubuh tersebut ditanamkan pada sel telur perempuan yang telah dihilangkan inti selnya.

\section{Pandangan Syariat dan Etika}

Secara singkat, kloning dapat berlangsung melalui proses pengambilan sel dari tubuh manusia, baik laki-laki ataupun perempuan, kemudian inti selnya diambil dan digabungkan dengan sel telur perempuan yang telah dibuang inti selnya. Sel telur ini lalu ditransfer ke dalam rahim perempuan agar memperbanyak diri, berkembang, berubah menjadi janin dan akhirnya dilahirkan sebagai bayi. Bayi yang dilahirkan merupakan keturunan dengan kode genetik yang sama dengan manusia yang menjadi sumber pengambilan sel tersebut.

Berkaitan dengan penciptaan manusia, Al-Quran menyatakan bahwa manusia diciptakan sebagai makhluk paling sempurna di antara seluruh makhluk yang ada dialam semesta (Al-Tin: 95): 4 yang berbunyi: "Sesungguhnya kami telah menciptakan manusia dalam bentuk yang sebaik-baikya". Berdasarkan kelebihan-kelebihan manusia, dapat dinyatakan bahwa usaha untuk mengkloning manusia unggul dinilai tidak tepat sasaran. Penjelasan Allah dalam Al-Quran tentang kesempurnaan penciptaan manusia diantara segala makhluk ciptaanNya yang lain, tidak dapat dibantah oleh orang-orang beriman. Dengan logika sederhana dapat digeneralisasi bahwa sesuatu yang sudah sempurna, kemudiaan disempurnakan lagi, tentu saja dapat menghilangkan sifat kesempurnaanya, bahkan bisa berakibat rusak sama sekali. Apalagi yang menyempurnakan adalah manusia yang terlahir dari hasil kreasi sang Maha Pencipta (Dito Nugroho, 2005).

Al-Quran membagi proses penciptaan manusia ke dalam 4 kategori. Kategori pertama adalah penciptaan manusia tanpa ayah dan ibu (creatio ex nihilo), yaitu Adam As. Kategori kedua adalah penciptaan manusia dari seorang "ayah" tanpa ibu, yaitu 
Hawa. Sedangkan kategori ketiga adalah penciptaan manusia dari seorang ibu tanpa ayah, yaitu Isa Al-Masih. Dan kategori keempat adalah penciptaan manusia biasa melalui perkawinan sepasang suami istri, yaitu manusia pada umumnya. Kategori pertama sampai ketiga dianggap merupakan hak mutlak Allah Swt, sehingga tidak dapat dipersoalkan secara teologis. Yang dapat dijadikan sebagai wacana teologis adalah kategori keempat, ketika manusia secara aktif mengambil peranan didalamnya. Pandangan Al-Quran tentang proses penciptaan manusia berdasarkan kategori keempat tersebut. Melalui pandangan ini kemudiaan ditentukan aspek teologis proses penciptaan manusia melalui mekanisme kloning (Dito Nugroho, 2005).

Melihat fakta kloning manusia secara menyeluruh, Abdul Qadim Zallum berpendapat dalam bukunya, Hukmu As Syar'i Fi al-intinsaakh, Naqlu al-a'dhaai, al-ijhaadh, Athfaalu al-anaabiib, ajhazatu, al-Ins'aasy, ath-thabiyah, al-Hayah wa al-maut, bahwa syariat mengharamkan kloning terhadap manusia, dengan argumentasi sebagai berikut. Pertama, anak-anak produk proses kloning dihasilkan melalui cara yang tidak alami (percampuran antara sel sperma dan sel telur). Padahal, cara alami inilah yang telah ditetapkan oleh syariat sebagai sunatullah menghasilkan anak-anak dan keturunannya. Allah SWT berfirman: "Dan bahwasannya Dialah yang menciptakan berpasang-pasangan laki-laki dan perempuan dari air mani apabila dipancarkan." (Q.S. An-Najm: 45-46) dalam ayat lain dinyatakan pula, "Bukankah dia dahulu setetes mani yag ditumpahkan (ke dalam rahim), kemudian mani itu menjadi segumpal darah, lalu Allah menciptakannya dan menyempurnakannya. Lalu Allah menjadikan daripadanya sepasang laki-laki dan perempuan." (Q.S. Al-Qiyamah: 37-38).

Kedua, anak-anak produk kloning dari perempuan -- tanpa adanya laki-laki -- tidak akan mempunyai ayah. Anak produk kloning tersebut jika dihasilkan dari proses pemindahan sel telur -- yang telah digabungkan dengan inti sel tubuh -- ke dalam rahim perempuan yang bukan pemilik sel telur, tidak pula akan 
memunyai ibu sebab rahim perempuan yang menjadi tempat pemindahan sel telur tersebut hanya menjadi penampung (mediator). Oleh karena itu, kondisi ini sesungguhnya telah bertentangan dengan firman Allah SWT, "Hai manusia, sesungguhnya Kami menciptakan kalian dari seorang laki-laki dan seorang perempuan" (Q.S. Al Hujuurat: 13) juga bertentangan dengan firman-Nya yang lain, "Panggillah mereka (anak-anak angkat itu) dengan (memakai) nama bapak-bapak mereka." (Q.S. Al-Ahzaab: 5).

Ketiga, kloning manusia akan menghilangkan nasab (garis keturunan). Padahal Islam telah mewajibkan pemeliharaan nasab. Ini berdasarkan hadis yang diriwayatkan dari Ibnu Abbas r.a. yang mengatakan bahwa Rasulullah SAW. telah bersabda, "Siapa saja yang menghubungkan nasab kepada orang yang bukan ayahnya, atau (seorang budak) bertuan (loyal/taat) kepada selain tuannya, maka dia akan mendapat laknat dari Allah, para malaikat dan seluruh manusia." (H.R. Ibnu Majah) Diriwayatkan pula dari Abu 'Utsman An Nahri r.a. yang berkata, "Aku mendengar Sa'ad dan Abu Bakrah masing-masing berkata, 'Kedua telingaku telah mendengar dan hatiku telah menghayati sabda Muhammad SAW., "Siapa saja yang mengaku-ngaku (sebagai anak) kepada orang yang bukan bapaknya, padahal dia tahu bahwa orang itu bukan bapaknya, maka surga baginya haram." (H.R. Ibnu Majah) Diriwayatkan pula dari Abu Hurairah r.a. bahwasannya tatkala turun ayat li'an dia mendengar Rasulullah saw. bersabda: "Siapa saja perempuan yang memasukkan kepada suatu kaum nasab (seseorang) yang bukan dari kalangan kaum itu, maka dia tidak akan mendapat apapun dari Allah dan Allah tidak akan pernah memasukkannya ke dalam surga. Dan siapa saja laki-laki yang mengingkari anaknya sendiri padahal dia melihat (kemiripan)nya, maka Allah akan akan tertutup darinya dan Allah akan membeberkan perbuatannya itu dihadapan orang-orang yang terdahulu dan kemudian (pada Hari Kiamat)" (H.R. Ad-Darimi) (Denny Kodrat, 2003). 
Kloning manusia yang bermotif memproduksi manusiamanusia unggul dalam hal kecerdasan, kekuatan fisik, kesehatan, kerupawanan -- jelas mengharuskan seleksi terhadap orangorang yang akan dikloning, tanpa memperhatikan apakah mereka suami-isteri atau bukan, sudah menikah atau belum. Selsel tubuh itu akan diambil dari perempuan atau laki-laki yang terpilih. Semua ini akan mengacaukan, menghilangkan dan membuat bercampur aduk nasab.

Keempat, memproduksi anak melalui proses kloning akan mencegah (baca: mengacaukan) pelaksanaan banyak hukumhukum syara' seperti hukum tentang perkawinan, nasab, nafkah, hak dan kewajiban antara bapak dan anak, waris, perawatan anak, hubungan kemahraman, hubungan 'ashabah, dan banyak lagi. Di samping itu, kloning akan mencampur-adukkan dan menghilangkan nasab serta menyalahi fitrah yang telah diciptakan Allah untuk manusia dalam masalah kelahiran anak. Konsekuensi kloning ini akan menjungkirbalikkan struktur kehidupan masyarakat (Denny Kodrat, 2003).

Pengharaman ini hanya berlaku untuk kasus kloning pada manusia a.n. sich. Kloning bagi hewan dan tumbuhan, apalagi bertujuan untuk mencari obat, justru dibolehkan bahkan disunahkan. Ini dapat dilihat dari dua hadis di bawah ini, "Sesungguhnya Allah Azza Wa Jalla setiap kali menciptakan penyakit, Dia menciptakan pula obatnya. Maka berobatlah kalian!." (H.R. Imam Ahmad) Imam Abu Dawud dan Ibnu Majah meriwayatkan dari Usamah bin Syuraik r.a. yang berkata, "Aku pernah bersama Nabi, lalu datanglah orang-orang Arab Badui. Mereka berkata, 'Wahai Rasulullah, bolehkah kami berobat?' Maka Nabi saw. menjawab, "Ya. Hai hamba-hamba Allah, berobatlah kalian sebab sesungguhnya Allah Azza wa Jalla tidaklah menciptakan penyakit kecuali menciptakan pula obat baginya...." Maka, berdasarkan nash ini diperbolehkan memanfaatkan proses kloning untuk memperbaiki kualitas tanaman dan hewan untuk mempertinggi produktivitasnya (Denny Kodrat, 2003). 
Berdasarkan keterangan tersebut dapat disimpulkan bahwa penciptaan manusia melalui kloning bertentangan dengan penciptaan manusia menurut Al-quran. Oleh karena itu, secara teologis kloning manusia otomatis bertentangan dengan akidah yang diyakini umat Islam. Dengan menggunakan logika teologis dapat disebutkan bahwa teknologi kloning tidak memasuki wilayah kekuasaan Tuhan. Tuhan dengan segala keagungan dan kekuasaan-Nya, tentu saja dapat menggagalkan seluruh usaha yang dilakukan manusia. Tanpa izin Tuhan segala sesuatu tidak mungkin terjadi. Realitas menunjukkan bahwa kloning telah berhasil diterapkan pada makhluk hidup, hal ini tidak mungkin terjadi bila Tuhan tidak mengizinkannya. Namun dari sudut pandang lain, kloning manusia dapat merusak tatanan teologi Islam. Menurut teologi Islam manusia pada umumnya dibekali tabiat dan kodrat untuk membedakan yang baik dan buruk. Dengan kloning manusia tabiat dan kodrat manusia itu tidak berfungsi lagi karena manusia kloning telah direkayasa sedemikian rupa untuk hanya dapat berbuat baik atau berbuat buruk saja sesuai dengan keinginan sang kreator. Perbuatan untuk mengubah makhluk ciptaan Allah merupakan satu perbuatan yang ditentang Allah (QS Al-Nisa: 119) (Dito Nugroho, 2005).

Perdebatan aspek etika penerapan teknologi kedokteran pada manusia berada dikawasan etika normatif, normative ethics. Dua landasan yang biasanya mendasari paham yang berbeda, yaitu deontologi dan teleologi. Pada deontologi, penilaian etis tidaknya suatu perbuatan lebih ditekankan kepada perbuatan itu sendiri. Sebaliknya, paham teleologi lebih menilai pada tujuan atau akibat yang dituju dari perbuatan itu. Dari aspek bioetika, yang paling tepat dalam membahas penerapan teknologi kloning pada manusia adalah menggunakan pendekatan melalui faham teleologi. Yang menjadi penilaian disini adalah apakah tujuan dan akibat yang ditimbulkan oleh penerapan teknologi kloning pada manusia ini baik atau tidak. Jika tujuannya untuk menolong pasangan suami istri yg tidak mungkin mempunyai anak sendiri, baik melalui preses reproduksi normal atau bayi tabung, maka 
kita dapat mengatakan bahwa tujuan itu baik maka secara etis tidak masalah. Jika tujuannya jahat maka secara etis ia tidak boleh dilakukan.

Perdebatan dapat dilanjutkan dengan mempertanyakan dapatkah etika dipisahkan dari agama, tata nilai dan moralitas masyarakat? Artinya, dalam hal kloning ini, kalau agama, tata nilai dan moralitas masyarakat (atau lebih tepatnya, para penafsir agama yang merasa dirinya sebagai representasi agama) sudah melarang, maka penerapan kloning sudah pasti jahat dan dengan demikian tidak boleh dilakukan. Pengetahuan tentang kloning terhadap manusia dapat saja dipelajari, tetapi pengamalan dan relalisasinya perlu dipertimbangkan sehati-hati mungkin. Adapun kloning terhadap makhluk biologis lain selain manusia, Nabi memberikan isyarat kebolehannya (Daulay, 2005).

Pada kloning, jika keragaman manusia telah hilang, maka secara etis hubungan antara manusia yang satu dengan yang lainnya akan menjadi rusak, karena orang lain dianggap sebagai cerminan dirinya sendiri. Kloning dapat juga menghilangkan nilai-nilai kemanusiaan dalam diri manusia. Komersialisasi dalam teknologi kloning dapat juga berpengaruh pada turunnya harkat dan martabat perempuan. Kloning dapat menimbulkan dampak yg cukup besar thd psikologi manusia kloning. Dominasi yang dilakukan oleh pihak manapun terhadap hidup orang lain jelas bertentangan dengan deklarasi universal hak-hak asasi manusia (universal declaration of human rights). (Dito Nugroho, 2005).

\section{E. Kesimpulan}

Dalam menemukan suatu hal yang baru atau discovery dan menentukan suatu hal yang masih gelap bagi orang lain (reaching the unknown) merupakan prinsip keilmuan dalam Al-Quran. Tetapi apapun yang diperoleh dari suatu riset dengan segala potensi yang ada pada manusia, penerapannya tidak boleh menyimpang dari nilai-nilai keadilan dan moral Al-Quran dan Sunnah Nabi. Islam memberikan prinsip-prinsip bagi manusia yang disebut sebagai alumuru al-hajjiyat yakni: menghilangkan apa saja yang memberatkan 
bagi kehidupan manusia, meringankan apa yang memberatkan kehidupan manusia, dan memberikan kemudahan pelaksanaan pada kondisi tertentu. Berdasarkan prinsip-prinsip tersebut, maka umat Islam dapat mengetahui kedudukan sekaligus dapat menilai mana yang diperbolehkan dan mana yang dilarang untuk dijauhi dalam tindakan dan perilaku tersebut.

Manusia sebagai makhluk yang paling sempurna dan mulia, diharapkan selalu memiliki derajat lebih ketimbang makhluk lain, sehingga jangan sampai mengalami degradasi akibat tangan manusia sendiri. Memang sebagian bisa memberi manfaat kepada mereka yang menghendaki, tetapi tampaknya mudlaratnya lebih besar ketimbang manfaatnya. Kendatipun diantaranya ada yang membolehkan, tetapi kebanyakan memandang bahwa kloning pada manusia membawa mudlarat yang lebih besar ketimbang manfaatnya. Sehingga mereka tidak membenarkan adanya kloning terhadap manusia. Akhirnya sampailah saya pada kesimpulan akhir yang akan menjawab pertanyaan pada sesi pembukaan di atas bahwa kloning pada manusia tidak akan pernah menjadi sesuatu yang etis dan normatif bagi kehidupan manusia.

\section{Kepustakaan}

Aziz Mushoffa dan Imam Musbikin, 2001. Kloning Manusia Abad XXI Antara Harapan, Tantangan dan Pertentangan. Forum Studi HIMANDA dan Pustaka Pelajar (Anggota IKAPI). Tebal: 222 halaman.

Aries Kelana, G.A. Guritno, dan Syahrir Wahab. 2001. "Menanti Dolly Bernama Manusia", dalam Gatra Nomor 40 Agustus 2001.

Atika Walujani M. 2001. "Kontropersi Kloning Manusia", dalam Pikiran Rakyat, 4 Desember 2001.

Daulay SP. 2005. Kloning dalam Perspektif Islam. Jakarta: Teraju.

Denny Kodrat. 2003. "Kontroversi Kloning Manusia Dalam Perspektif SyariatSelasa", dalam Pikiran Rakyat Senin 13 Januari 2003.

Dito Anurogo, 2005. Tinjauan Agama, Etik, dan Medis Tentang Kloning. Semarang: Fakultas Kedokteran Universitas Islam Sultan Agung Semarang. 
Soetandyo Wignjosoebroto. 1997. "Kloning: Kemungkinan Teknis dan Implikasi Permasalahan Sosial-Etisnya", dalam makalah Sarasehan Nasional Surabaya.

Yahya, Harun. 2003. Runtuhnya Teori Evolusi dalam 20 Pertanyaan. Surabaya: Risalah Gusti.

\section{Tentang Penulis :}

Aman, M.Pd. Dosen Jurusan Pendidikan Sejarah Fakultas Ilmu Sosial Universitas Negeri Yogyakarta. Menyelesaikan Program Sarjana pada Jurusan Pendidikan Sejarah FIS UNY lulus tahun 1999, dan menyelesaikan Program Magister Pendidikan Sejarah pada PPS Universitas Negeri Yogyakarta. Saat ini mengampu mata kuliah Sejarah Tata Negara, Sejarah Indonesia Abad ke-19, Seminar Sejarah, Evaluasi Pembelajaran Sejarah, Dasar-dasar Statistik, Strategi Pembelajaran Sosiologi, dan Perencanaan Pembelajaran Sosiologi. 